Economics Development Analysis Journal 5(2)(2016)

\title{
Pengaruh Human Capital Spillover Effects terhadap Produktivitas Industri Pengolahan Kawasan Kedungsepur
}

Sessa Anata Salam ${ }^{1}$, Bambang Prishardoyo ${ }^{2}$

Jurusan Ekonomi Pembangunan, Fakultas Ekonomi, Universitas Negeri Semarang

\section{Info Artikel}

Sejarah Artikel:

Diterima Januari 2016

Disetujui Maret 2016

Dipublikasikan Mei 2016

\section{Keywords:}

Cobb-Douglas; Spillover;

Kedungsepur; Productivity

\begin{abstract}
Abstrak
Tujuan dari penelitian ini untuk mengetahui terdapat atau tidaknya pengaruh human capital spillover effects terhadap produktivitas industri pengolahan di Kawasan Kedungsepur. Industrialisasi sejak masa orde baru periode 1967-1997 telah mengubah struktur perekonomian Indonesia. Kawasan Kedungsepur menjadi lokasi penelitian dikarenakan terdapatnya potensi dalam bidang industri dibandingkan dengan 8 (delapan) kawasan strategis lainnya di Provinsi Jawa Tengah. Pada tahun 2007-2012 perkembangan PDRB sektor industri pengolahan cenderung mengalami penurunan. Salah satu yang mempengaruhi produktivitas ialah SDM yang berkualitas, sehingga peneliti ingin melihat apakah terdapat pengaruh Human Capital Spillove Effects serta pengaruh dari faktor lainnya seperti tenaga kerja industri dengan tingkat pendidikan rendah dan tingkat pendidikan tinggi, modal industri serta upah terhadap produktivitas industri pengolahan pada Kawasan Kedungsepur. Penelitian ini menggunakan fungsi produksi Cobb-Douglas. Metode analisis yang digunakan berupa Ordinary Least Squares dengan menggunakan regresi data panel. Berdasarkan hasil penelitian tidak ditemukan adanya pengaruh dari tenaga kerja industri dengan tingkat pendidikan rendah. Kesimpulan penelitian ini ialah, ditemukan Human Capital Spillover Effect terhadap produktivitas industri pengolahan pada kawasan Kedungsepur. Tenaga kerja industri pendidikan rendah tidak berpengaruh secara nyata, angkatan kerja di luar industri dengan tingkat pendidikan tinggi, tenaga kerja industri dengan tingkat pendidikan tinggi, modal industri dan upah berpengaruh secara nyata dan positif terhadap produktivitas industri kawasan Kedungsepur.
\end{abstract}




\section{PENDAHULUAN}

Industrialisasi sejak masa Orde Baru selama periode 1967-1997 telah mengubah struktur perekonomian Indonesia. Peranan sektor industri pengolahan telah mencapai 26,8 $\%$ dari PDB, sedangkan peranan sektor pertanian tercatat 16,1 \% (Kina, 2008:4). Peranan sektor industri selain memberi nilai tambah yaitu dapat menyerap tenaga kerja, memenuhi kebutuhan dalam negeri, memiliki potensi pengembangan ekspor, dan dapat meningkatkan penerapan standarisasi produk industri pengolahan sebagai faktor penguat daya saing produk nasional. Penelitian dilakukan di Kawasan "Kedungsepur" yang mencakup 4 kabupaten yaitu Kabupaten Kendal, Demak, Ungaran, dan Purwodadi, serta 2 kota yaitu Kota Salatiga dan Semarang. Kawasan Kedungsepur dijadikan sebagai lokasi penelitian dikarenakan memiliki potensi sektor industri yang lebih besar dibandingkan dengan kawasan strategis lainnya. Hal tersebut dapat dilihat pada grafik PDRB sektor industri di bawah ini:

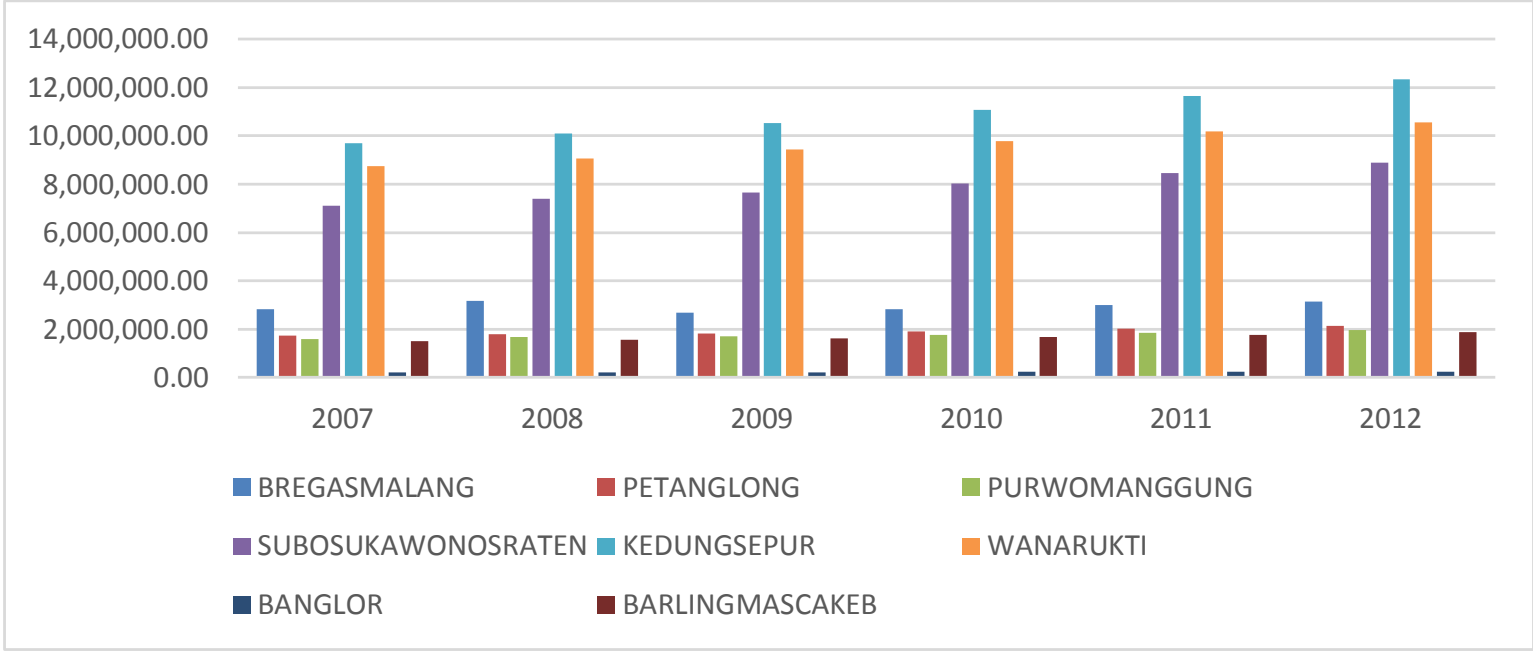

Sumber: BPS, diolah. 2015

Gambar 1. PDRB Sektor Industri Pada 8 (Delapan) Wilayah Strategis di Provinsi Jawa Tengah ADHK 2000

Pada grafik di atas dapat dilihat perkembangan PDRB sektor industri pada 8 wilayah strategis di Provinsi Jawa Tengah dipimpin oleh Kawasan Kedungsepur. PDRB sektor industri dengan nilai paling rendah berada pada kawasan Banglor. Hal itu merupakan alasan mengapa kawasan Kedungsepur menjadi lokasi penelitian, karena memiliki potensi yang bagus dalam perindustrian di Provinsi Jawa Tengah.

Kabupaten/kota pada kawasan Kedungsepur telah memberikan kontribusi sekitar $17 \%$ pertahunnya dari output sektor industri pengolahan di Jawa Tengah.
Kawasan Kedungsepur juga menyumbang lebih dari $31 \%$ dari total PDRB yang dihasilkan Provinsi Jawa Tengah. Permasalahan yang terjadi adalah perkembangan sumbangan yang diberikan wilayah Kedungsepur terhadap PDRB di Jawa Tengah pada sektor industri pengolahan cenderung mengalami penurunan di tahun 2011 dari sebesar $33 \%$ menjadi $32 \%$ di tahun 2012 . Berikut kontribusi sektor industri pengolahan di Kawasan Kedungsepur terhadap produk domestik regional bruto Provinsi Jawa Tengah dimulai tahun 2007 hingga tahun 2012: 
Tabel 1. Kontribusi Sektor Industri Pengolahan Kawasan Kedungsepur terhadap Produk Domestik Regional Bruto Provinsi Jawa Tengah Tahun 2007-2012 Atas Dasar Harga Konstan Tahun 2000 (Juta Rupiah)

\begin{tabular}{llllllll}
\hline Tahun & \multicolumn{3}{l}{ PDRB Sektor Industri Pengolahan } & & \multicolumn{2}{l}{ Total PDRB } \\
& \cline { 2 - 5 } & $\begin{array}{l}\text { Kedungsepur } \\
\text { (Juta Rupiah) }\end{array}$ & $\begin{array}{l}\text { Prov. Jateng } \\
\text { (Juta Rupiah) }\end{array}$ & $\begin{array}{l}\text { Persen } \\
(\%)\end{array}$ & $\begin{array}{l}\text { Laju } \\
\text { (\%) }\end{array}$ & & $\%$ \\
\hline 2007 & $9,697,898.71$ & $50,870,785.69$ & 19.06 & 5.56 & $159,110,253.77$ & 31.97 \\
2008 & $10,108,595.40$ & $55,348,962.88$ & 18.26 & 4.5 & $167,790,369.85$ & 32.98 \\
2009 & $10,522,820.36$ & $57,444,185.45$ & 18.31 & 1.84 & $176,673,456.57$ & 32.51 \\
2010 & $11,076,545.22$ & $61,390,101.24$ & 18.04 & 6.87 & $186,992,985.50$ & 32.83 \\
2011 & $11,644,249.24$ & $65,439,443.00$ & 17.79 & 6.74 & $198,270,117.92$ & 33.00 \\
2012 & $12,338,599.69$ & $69,012,495.82$ & 17.87 & 5.46 & $210,848,424.06$ & 32.73 \\
Jumlah & 65388708.62 & $359,505,974.08$ & 100 & & $1,099,685,607.67$ & 100 \\
\hline
\end{tabular}

Sumber: Jawa Tengah Dalam Angka 2008-2013, BPS Provinsi Jawa Tengah, diolah

Berdasarkan tabel 1 dapat dilihat bahwa PDRB sektor industri pengolahan pada Kawasan Kedungsepur meningkat secara signifikan. Jika dilihat dalam bentuk persentase kontribusi sektor industri pengolahan cenderung mengalami naikturun dari tahun 2007 hingga tahun 2012. Tahun 2007 dapat berkontribusi sebesar $19 \%$, namun di tahun 2012 hanya memberikan $17.8 \%$ terhadap sektor industri pengolahan PDRB di Jawa Tengah.

Kawasan Kedungsepur memiliki sekitar kurang lebih 600 perusahan industri besar dan sedang dengan jumlah tenaga kerja sebanyak kurang lebih 218.842 ribu jiwa. Kota Semarang, Kabupaten Ungaran dan Kabupaten Demak sebagai kawasan industri utama di Jawa Tengah termasuk di dalam kawasan strategis wilayah Kedungsepur, sehingga dapat dikatakan bahwa Kawasan Kedungsepur memiliki potensi untuk meningkatkan kontribusi industri pengolahannya terhadap PDRB Provinsi Jawa Tengah sehingga diharapkan dengan terdapatnya kawasan industri utama di wilayah Kedungsepur akan merangsang berdirinya industri baru yang dapat saling menunjang satu-sama-lain.

Sasaran pembangunan industri salah satunya ialah dapat menyerap tenaga kerja. Upah merupakan salah satu dari masalah tenaga kerja yang kompleks karena selalu muncul dalam pembahasan tentang tenaga kerja disamping masalah hubungan industrial antara pekerja dan dunia usaha (Sholeh, 2011:1). Dalam beberapa industri, upah yang lebih rendah berhubungan dengan output yang lebih tinggi, dan alasan untuk hubungan yang positif di industri lain bisa karena daya tawar pekerja (Blaga \& Jozsef, 2014).

Sukirno (dalam Sulaeman, 2014:93), menyatakan bahwa upah dalam teori ekonomi diartikan sebagai pembayaran yang diperoleh berbagai bentuk jasa yang disediakan dan diberikan oleh para pengusaha kepada tenaga kerja. Penelitian Sumarlin et al (dalam Sulaeman, 2014:93) disebutkan bahwa produktivitas pekerja tergantung pada tingkat upah yang mereka terima. Hal tersebut dapat dicontohkan, apabila tenaga kerja mendapatkan upah yang tinggi maka mereka dapat memenuhi standar kebutuhan hidup dengan mengkonsumsi makanan yang bergizi sehingga membuat tubuh menjadi sehat, sehingga mereka dapat bekerja lebih efektif dan dapat meningkatkan produktivitas. Selain upah, modal juga dapat mempengaruhi produktivitas suatu industri. Hal tersebut di ambil dari teori Cobb-Douglas, melalui teori produksi.

Selain upah dan modal, yang dibutuhkan dalam industri pengolahan ialah sumber daya manusia yang berkualitas. Sumber daya manusia 
yang berkualitas merupakan salah satu faktor yang dipertimbangkan pengaruhnya karena dapat berperan menguasai teknologi yang selanjutnya dapat meningkatkan produktivitas. Lingkaran kualitas adalah salah satu cara praktis yang paling luas untuk pemulihan yang lebih tinggi dari sumber daya manusia dan ini dapat dicapai melalui kerjasama. Menciptakan lingkaran kualitas harus dilakukan untuk peningkatan aktivitas, secara umum, dan kapasitas produksi, khususnya (Battacharya \& Narayan, 2015) .

Modal manusia yang berkualitas dapat terjadi ketika terjadi limpahan pengetahuan atau knowledge spillover. Knowledge Spillover atau sebaran pengetahuan terjadi karena adanya interaksi antara individu satu dengan individu lainnya baik antar masyarakat umum maupun antar para pekerja yang saling bertukar ilmu satu sama lain atau dapat disebut Human Capital Spillover. Abbas (2010:10), menyatakan bahwa dalam jangka panjang modal manusia memiliki pengaruh positif dan signifikan terhadap output. Pertumbuhan tahunan output per kapita dipengaruhi secara positif oleh variabel lama bersekolah dan kualitas tenaga kerja. Pada penelitian ini Human Capital akan dikelompokan menjadi dua jenis dalam bentuk tenaga kerja industri dengan tingkat pendidikan rendah (TKIR) dan tenaga kerja industri dengan tingkat pendidikan tinggi (TKIT). Sistem pendidikan menjadi refleksi dari kualitas lulusan dan kesiapan untuk keterampilan yang dibutuhkan (Soukalova \& Gottlichova, 2015).

Penelitian ini diharapkan dapat menjawab apakah terdapat pengaruh human capital spillover effects terhadap produktivitas industri pengolahan pada kawasan Kedungsepur; dan bagaimana pengaruh tingkat pendidikan angkatan kerja (di luar industri), tenaga kerja industri pengolahan dengan tingkat pendidikan rendah, tenaga kerja industri pengolahan dengan tingkat pendidikan tinggi, modal industri, dan upah terhadap produktivitas industri pengolahan pada kawasan Kedungsepur.
Adapun tujuan dari penelitian ini untuk mengetahui terdapat atau tidaknya pengaruh human capital spillover effects terhadap produktivitas industri pengolahan di Kawasan Kedungsepur; dan untk mengetahui pengaruh angkatan kerja di luar industri pengolahan dengan tingkat pendidikan tinggi, tenaga kerja industri pengolahan dengan tingkat pendidikan rendah, tenaga kerja industri pengolahan dengan tingkat pendidikan tinggi, modal industri, dan upah terhadap produktivitas industri pengolahan pada kawasan Kedungsepur.

Penelitian ini menggunakan pendekatan produktivitas dari fungsi produksi Cobb-Douglas. Fungsi produksi Cobb-Douglass sering digunakan untuk pengukuran produktivitas. Joesron (2012; 118-119) fungsi Cobb-Douglass secara matematis dapat dituliskan dengan persamaan sebagai berikut:

$$
\mathrm{Q}=\mathrm{A} \mathrm{La} \mathrm{Kb}
$$

\section{Keterangan :}

$$
\begin{array}{ll}
\mathrm{Q} & =\text { Output } \\
\mathrm{A} & =\text { Konstanta } \\
\mathrm{L} & =\text { Labor atau tenaga kerja } \\
\mathrm{K} & =\text { Kapital atau modal } \\
\mathrm{a}, \mathrm{b} & =\text { Elastisitas input faktor produksi. }
\end{array}
$$

Karena model tersebut belum linier, untuk dapat mengolah data dan dianalisis lebih lanjut, data-data yang diperoleh terlebih dahulu harus ditransformasikan kebentuk Logaritma Natural. Maka akan diperoleh fungsi:

$$
\operatorname{Ln} Q=\operatorname{Ln} A+\operatorname{Ln} \alpha \mathrm{L}+\operatorname{Ln} \beta \mathrm{K}
$$

Produktivitas sendiri dapat didefinisikan sebagai produksi yang diciptakan oleh seorang pekerja pada suatu waktu tertentu (Sukirno, 2005:353). Mankiw (2006), produktivitas mengacu kepada kuantitas barang dan jasa yang bisa dihasilkan seorang pekerja per jam-kerja. Kenaikan produktivitas dapat diartikan bahwa para pekerja tersebut dapat menghasilkan lebih banyak barang pada jangka waktu yang sama. 
Salah satu yang mempengaruhi produktivitas merupakan modal manusia yang berkualitas.

Modal manusia (human capital) merupakan akumulasi dari investasi yang dilakukan manusia, seperti menambah pendidikan dan melakukan latihan kerja. Mankiw, (2006:407). Sehingga dapat dikatakan bahwa modal manusia adalah bentuk dari investasi yang dilakukan manusia baik berupa pendidikan maupun kesehatan untuk menambah keahlian, ketrampilan, pengalaman dan pengetahuan sehingga menjadi sumber daya manusia yang berkualitas.

Modal manusia yang berkualitas dapat terjadi ketika terjadi limpahan pengetahuan atau knowledge spillover. Knowledge Spillover atau sebaran pengetahuan terjadi karena adanya interaksi antara individu satu dengan individu lainnya baik antar masyarakat umum maupun antar para pekerja yang saling bertukar ilmu satu sama lain. Sjoholm (1999) (dalam Margiantonius, 2010:29), menyebutkan bahwa E. Glaeser, H. Kallal, J. Scheinkman, dan A.

Schleifer membagi teori pertumbuhan regional menjadi tiga kelompok yaitu, teori yang berdasarkan studi A. Marshall, K.j. Arrow dan P. Romer (yang selanjutnya disingkat menjadi studi MAR); teori yang berdasarkan studi M.E., Porter; dan teori yang berdasarkan stufi J.Jacobs. Semua teori tersebut berpendapat bahwa knowledge spillover merupakan faktor yang pentig dalam pertumbuhan

Selain tenaga kerja, upah juga dapat mempengaruhi produktivitas.

Sukirno (2003:353), menyatakan bahwa upah dalam teori ekonomi diartikan sebagai pembayaran yang diperoleh berbagai bentuk jasa yang disediakan oleh para pengusaha dan diberikan kepada tenaga kerja.

Penelitian Sumarlin et al dalam Sulaeman (2014:93) disebutkan bahwa produktivitas pekerja tergantung pada tingkat upah yang mereka terima.
Semakin besar tingkat upah dinaikkan, akan semakin besar pula perubahan output yang terjadi (Juhaari \& Atmanti, 2009:100).

\section{METODE PENELITIAN}

Jenis data yang digunakan pada penelitian ini merupakan data yang bersumber dari data sekunder. Data sekunder adalah analisis atas data yang sudah tersedia. Sedangkan data pendukung, diperoleh melalui sumber bacaan dari website pemerintahan. Data yang akan digunakan pada penelitian ini adalah data panel. Terdapat beberapa teknik yang ditawarkan untuk mengestimasi parameter model dengan data panel, seperti: (i) Koefisien tetap Antara Waktu dan Individu (Common Effect), teknik ini tidak berbeda dengan teknik regresi data cross section atau time series tetapi, untuk data panel sebelum membuat regresi kita harus menggabungkan data cross-section dengan data time series (pool data). Kemudian data gabungan ini diperlakukan sebagai suatu kesatuan pengamatan untuk mengestimasi model dengan metode OLS. Metode ini dikenal dengan estimasi Common Effect; (ii) Model Efek Tetap (Fixed Effect), pada pembahasan sebelumnya kita mengasumsikan bahwa intersep maupun slope adalah sama baik antar waktu maupun antar perusahaan. Namun, asumsi ini jelas sangat jauh dari kenyataan sebenarnya. Adanya variabel-variabel yang tidak semuanya masuk dalam persamaan model memungkinkan adanya intercept yang tidak konstan; dan (iii) Model Efek Random (Random Effect), perbedaan antar-individu dan atau waktu dicerminkan lewat intercept, maka pada Model Random Effect, perbedaan tersebut diakomodasi lewat error. Teknik ini juga memperhitungkan bahwa error mungkin berkorelasi sepanjang time series dan cross section

\section{HASIL DAN PEMBAHASAN}

Teknik regresi data panel memiliki 3 (tiga) teknik untuk menentukan model, yaitu common effect model, fixed effect model dan random effect model. Pada penelitian ini, untuk mengestimasi 
angkatan kerja di luar industri dengan tingkat pendidikan tinggi, tenaga kerja industri dengan pendidikan rendah, tenaga kerja industri dengan pendidikan tinggi, modal industri dan upah, maka digunakan model sebagai berikut:

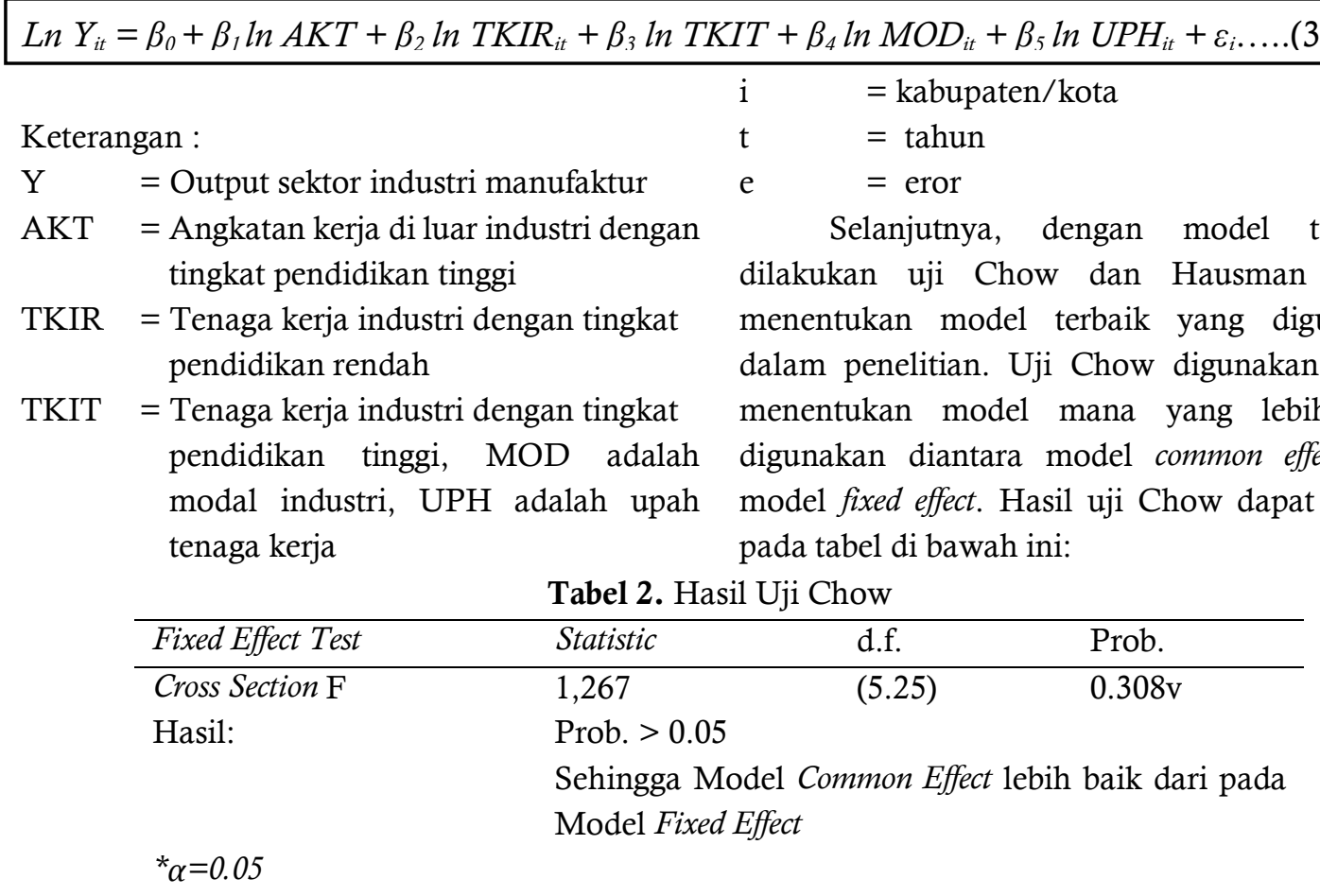

Sumber: Hasil uji Chow dengan EViews 6.0. Peneliti, diolah. 2015.

Berdasarkan pada tabel 2 di atas, diketahui bahwa hasil dari Cross Section $F$ memiliki dengan nilai sebesar $0.308>0.005$. Oleh karena itu, dapat diambil keputusan bahwa model yang lebih baik digunakan ialah model Common Effect.

Uji Hausman merupakan sebuah uji lanjutan dari uji Chow untuk menentukan model mana yang lebih baik digunakan antara model Fixed Effect dan model Random Effect. Namun dikarenakan pada pengujian sebelumnya atau pengujian Chow model yang lebih baik digunakan ialah model Common Effect, maka pengujian Hausman tidak lagi diperlukan.

Setelah melakukan uji spesifikasi model untuk memilih model yang mana yang lebih baik digunakan dalam penelitian ini, maka terpilih Common Effect Model dengan hasil regresi sebagai berikut:

Tabel 3. Hasil Regresi Dengan Common Model dengan Cross-Weighted

\begin{tabular}{|c|c|c|c|c|c|}
\hline Variabel & Koefisien & $\begin{array}{l}\text { Std. } \\
\text { Error }\end{array}$ & Prob & F-Stat & t-Stat \\
\hline Konstanta & 2,035 & 0,585 & 0,001 & \multirow[t]{7}{*}{946,361} & 3,475 \\
\hline Angkatan Kerja Pendidikan Tinggi (AKT) & 0,079 & 0,034 & 0,031 & & 2,260 \\
\hline Tenaga Kerja Pendidikan Rendah (TKIR) & $-0,019$ & 0,012 & 0,137 & & $-1,527$ \\
\hline Tenaga Kerja Pendidikan Tinggi (TKIT) & 0,053 & 0,028 & 0,071 & & 1,867 \\
\hline Modal (MOD) & 0,837 & 0,051 & 0,000 & & 16,299 \\
\hline Upah (UPH) & 0,136 & 0,049 & 0,009 & & 2,777 \\
\hline${ }^{*} \alpha=0.10 * * F-$ tabel $=2.69 * * *$ t-tabel $=1,69$ & 697 & & & & \\
\hline
\end{tabular}

Sumber: Penulis, data diolah, 2015. 
Dilihat dari persamaan pada tabel 3, maka diperoleh hasil bahwa F-Statistik $>$ F-Tabel atau $946,361>2,69$, yang artinya semua variabel

independent (angkatan kerja di luar industri dengan tingkat pendidikan tinggi, tenaga kerja industri dengan tingkat pendidikan pendidikan

rendah, tenaga kerja industri dengan tingkat pendidikan tinggi, modal industri dan upah) secara bersama-sama memiliki pengaruh yang nyata terhadap variabel dependent yang dalam hal ini ialah produktivitas industri pengolahan di Kawasan Kedungsepur dengan tingkat kepercayaan sebesar 95\%.

Angkatan kerja di luar industri pengolahan dengan tingkat pendidikan tinggi merupakan variabel spillover dalam penelitian ini. Hasil estimasi pada variabel angkatan kerja di luar industri pengolahan dengan tingkat pendidikan tinggi (AKT) berpengaruh secara positif dan nyata terhadap produktivitas industri pengolahan di kawasan Kedungsepur dengan hasil uji t sebesar 2,260 > 1,697. Nilai koefisien dari hasil regresi berganda pada variabel angkatan kerja dengan tingkat pendidikan tinggi (AKT) tercatat sebesar 0,079 yang berarti bahwa setiap kenaikan jumlah angkatan kerja di luar industri dengan tingkat pendidikan tinggi sebesar $1 \%$, maka produktivitas industri pengolahan akan naik sebesar 0,079\%.

Hasil estimasi pada variabel tenaga kerja industri dengan tingkat pendidikan rendah (TKIR) berpengaruh secara negatif namun tidak nyata terhadap produktivitas industri pengolahan di kawasan Kedungsepur karena memiliki hasil uji t sebesar $-1,527<-1,310$.

Nilai koefisien pada variabel tenaga kerja industri dengan tingkat pendidikan rendah (TKIR) tercatat sebesar -0,019, yang berarti bahwa setiap kenaikan jumlah tenaga kerja industri dengan tingkat pendidikan rendah sebesar 1\%, maka produktivitas industri pengolahan akan turun sebesar 0,019\%.

Hasil estimasi pada variabel tenaga kerja industri dengan tingkat pendidikan tinggi (TKIT) berpengaruh secara positif dan nyata terhadap produktivitas industri pengolahan di kawasan Kedungsepur dengan nilai uji t sebesar 1,867 > 1,697. Nilai koefisien pada variabel tenaga kerja industri dengan tingkat pendidikan tinggi (TKIT) tercatat sebesar 0,053 , yang berarti bahwa setiap kenaikan jumlah tenaga kerja industri dengan tingkat pendidikan tinggi sebesar 1\%, maka produktivitas industri pengolahan akan naik sebesar $0,053 \%$.

Hasil estimasi pada variabel modal (MOD) berpengaruh secara positif dan nyata terhadap produktivitas industri pengolahan di kawasan Kedungsepur dengan nilai uji t sebesar 16,299 > 1,697. Nilai koefisien pada variabel modal (MOD) tercatat sebesar 0,837, yang berarti bahwa setiap kenaikan modal sebesar $1 \%$, maka produktivitas industri pengolahan akan naik sebesar $0,837 \%$.

Hasil estimasi pada variabel upah (UPH) berpengaruh secara positif dan nyata terhadap produktivitas industri pengolahan di kawasan Kedungsepur dengan hasil uji t sebesar 2,777< 1,697. Nilai koefisien pada variabel upah (UPH) tercatat sebesar 0,136 , yang berarti bahwa setiap kenaikan upah sebesar 1\%, maka produktivitas industri pengolahan akan naik sebesar $0,136 \%$.

Semakin bertambahnya jumlah variabel bebas pada sebuah penelitian akan meningkatkan nilai R-Squared nya, oleh karena itu digunakan Adjusted R-Squared yang merupakan R-Squared yang sudah mempertimbangkan derajat bebasnya. Berikut merupakan hasil dari Adjusted $R$-Squared yang telah diolah dengan EViews 6.0:

Tabel 4. Hasil Adjusted R-Squared

\begin{tabular}{|l|l|}
\hline Adjusted R-Squared & 0.992 \\
\hline
\end{tabular}

Sumber: Peneliti, diolah EViews 6.0. 2015 
Berdasarkan tabel 4 di atas, diketahui bahwa Adjusted R-Squared dalam penelitian ini memiliki nilai sebesar 0,992 yang artinya bahwa variabel independen mampu menjelaskan varian dari variabel dependen sebesar $99,2 \%$.

\section{SIMPULAN}

Berdasarkan hasil penelitian yang dilakukan oleh penulis, maka diperoleh beberapa kesimpulan. Kesimpulan pertama ialah ditemukannya pengaruh Human Capital Spillover secara nyata dan positif terhadap kenaikan produktivitas industri pengolahan pada kawasan Kedungsepur, Jawa Tengah. Terdapatnya Human Capital Spillover Effects pada produktivitas industri pengolahan di Kawasan Kedungsepur, maka diperlukan bantuan dari pemerintah daerah untuk menyatukan peran dari dunia industri dengan dunia akademis agar transfer ilmu pengetahuan dapat terjadi secara optimal. Kedua, tenaga kerja industri dengan tingkat pendidikan rendah tidak memberikan pengaruh secara nyata terhadap pertumbuhan produktivitas industri pengolahan pada kawasan Kedungsepur, sedangkan tenaga kerja industri dengan tingkat pendidikan tinggi, modal industri, dan upah memberikan pengaruh yang positif dan signifikan terhadap produktivitas industri pengolahan pada kawasan Kedungsepur. Melihat bahwa tingkat pendidikan tenaga kerja industri yang bekerja pada industri pengolahan ternyata memiliki pengaruh yang signifikan terhadap produktivitas industri pengolahan pada kawasan Kedungsepur, hal ini membuktikan bahwa tingkat pendidikan memiliki peran yang penting, sehingga kepada Dinas Pendidikan akan lebih baik apabila memperhatikan kualitas tingkat pendidikan penduduk di kawasan Kedungsepur agar meningkatkan modal manusia yang berada pada kawasan tersebut sehingga diharapkan akan terjadi pengembangan inovasi dan transfer teknologi dalam rangka memajukan industri di Kawasan Kedungsepur.

\section{DAFTAR PUSTAKA}

Abbas, Tarmizi. 2010. Modal Manusia dan Pertumbuhan Ekonomi. Universitas Malikussaleh.

Badan Pusat Statistik. 2008-2013. Jawa Tengah Dalam Angka. Semarang : Badan Pusat Statistik.

Bhattacharya, M. \& Narayan, P., 2015. Output And Labor Productivity In Organized Manufacturing: A Panel Cointegration Analysis For India. International Journal of Production Economics, 170, pp.171 - 177.

Blaga, P. \& Jozsef, B., 2014. Human Resources, Quality Circles And Innovation. Procedia Economics and Finance, 15, pp.1458 - 1462.

Farhanah, L., \& Azizah, R. (2013). Optimalisasi Penyerapan Tenaga Kerja Indonesia Melalui Pengembangan Human Capital Dan Penyediaan Jaringan Kerja Online Yang Terintegrasi Secara Nasional. Economics Development Analysis Journal, 2(2). doi:10.15294/edaj.v2i2.1403

Joesron, T.S. 2012. Teori Ekonomi Mikro.Yogyakarta: Graha Ilmu.

Juhaari, I., \& Atmanti, H. (2012). Dampak Perubahan Upah Terhadap Output Dan Kesempatan Kerja Iindustri Manufaktur Di Jawa Tengah. Jejak: Jurnal Ekonomi Dan Kebijakan, 2(2). doi:http://dx.doi.org/10.15294/jejak.v2i2.14 62

Kina. 2008. Peranan Industri Dalam Pemulihan Ekonomi Nasional. Jakarta: Departemen Perindustrian.

Kodar, N. 2014. Analisis Pengaruh Human Capital Investment Terhadap Pertumbuhan Ekonomi di Jawa Tengah.Surakarta: Universitas Muhammadyah Surakarta.

Mankiw, N. Gregory. 2006. Principles of Microeconomics: Fourth Edition. SouthWestern: Cengage South-Western.

Margiantonius, O. 2010. Analisis Efek Limpahan Modal Manusia Terhadap Produktivitas Industri Manufaktur di Kawasan Gerbangkertasusila. Yogyakarta: Universitas Gajah Mada.

Maulana, R. (2015). Pengaruh Human Capital Terhadap Pertumbuhan Ekonomi Regional Di Provinsi Jawa Tengah Tahun 2008-2012. Economics Development Analysis Journal, 4(2). doi:10.15294/edaj.v4i2.6734. 
Nuryadin, D., S, J., Iskandar, D. 2007. Aglomerasi dan Pertumbuhan Ekonomi: Peran Karakteristik Regional di Indonesia. Depok: Universitas Indonesia

Olayemi, Simon-Oke O. 2012. Human Capital Investment and Industrial Productivity in Nigeria. Nigeria: Federal University of Technology.

Santoso, A. 2007. Analisis Feel Limpahan Modal Manusia Antar Industri Manufaktur Besar dan Sedang di Kota Medan, Batam, Palembang, Jakarta, Surabaya, Banjarmasin, dan Makassar Pada Periode 1995-1997. Depok: Universitas Indonesia.

Sari, N. (2015). Konsentrasi Industri Pengolahan di Propinsi Jawa Tengah. Economics Development Analysis Journal, 3(3). doi:10.15294/edaj.v3i3.1038.

Sholeh, M. 2011. Metode Edutainment. Jogjakarta: DIVA Press.

Soukalova, R. \& Gottlichova, M., 2015. The Impact of Effective Process of Higher Education on The Quality of Human Resources In The Czech Republic. Procedia-Social and Behavioral Sciences, 174, pp.3715 - 3723.

Sukirno, S. 2003. Pengantar Ekonomi Mikro. Jakarta: Rajawali Press.

Sulaeman, Ardika. 2014. Pengaruh Upah dan Pengalaman Kerja terhadap Produktivitas Karyawan Kerajinan Ukiran Kabupaten Semarang. Subang: STIE Miftahul Huda Subang.

Todaro, M.P., Stephen. 2004. Pembangunan Ekonomi di Dunia Ketiga. Jakarta: Erlangga

Wilson, R. A., Briscoe, G. 2004. The Impact of Human Capital on Economic Growth: a review. Europe: Cadefop. 